\title{
Aflaj's Irrigation Water Demand/Supply Ratio: Two Case Studies
}

\author{
Abdullah Al-Ghafri \\ Department of Soils, Water and Agricultural Engineering, College of Agricultural \\ and Marine Sciences, Sultan Qaboos University \\ P.O. Box 34, Al-Khod 123, Sultanate of Oman

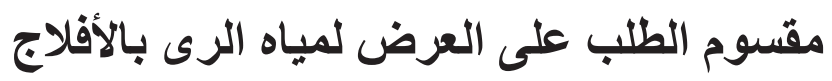 \\ عبدالله الغاقري

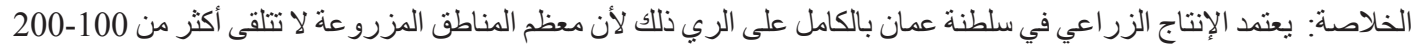

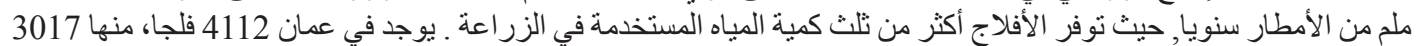

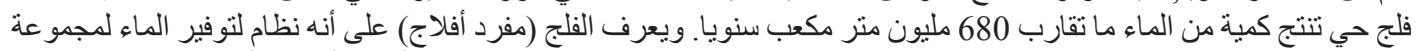

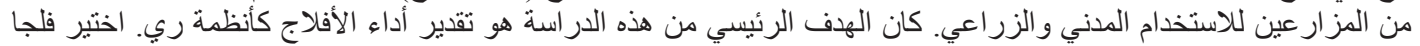

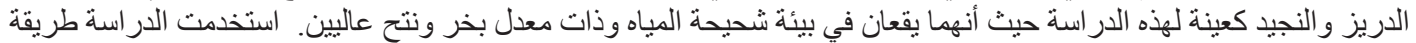

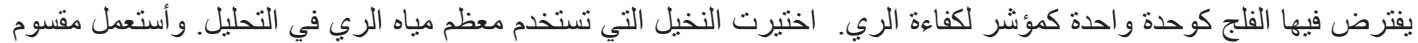

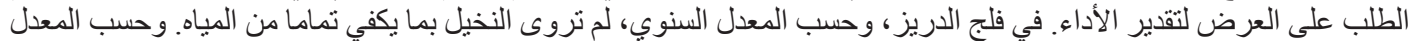

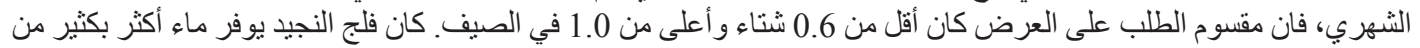

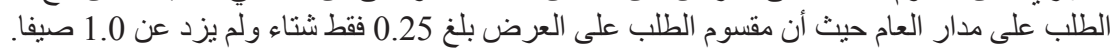

ABSTRACT: Due to the geographical location of Oman in an arid zone, agricultural production depends fully on irrigation. The traditional irrigation systems (Aflaj, sing. falaj) supply more than one third of water for agriculture. Falaj is defined in the context of this paper as a canal system which provides water for domestic and agricultural uses. Oman has 3,107 active Aflaj producing about $680 \mathrm{Mm}^{3}$ of water per year. The main objective of this study was to estimate the irrigation performance of Aflaj in Oman. Falaj al-Dariz and al-Nujaid were chosen as case studies. Both Aflaj are located in an extremely arid environment, where the rainfall is low and evapotranspiration is high. The study utilized an approach to estimate the irrigation performance of Aflaj by considering the falaj as a single unit of irrigation. The irrigation demand/supply ratio (D/S) was used in the analysis as a tool of evaluation. Date palm, the dominant crop irrigated by Aflaj, was selected for the analysis. In falaj al-Dariz the date palms were slightly under irrigated on a yearly basis. On a monthly basis, in winter, the D/S was below 0.6 and in summer it was above 1.0. On the other hand, falaj al-Nujaid was supplying too much water than the date palms needed all round the year. In winter the $\mathrm{D} / \mathrm{S}$ ratio was as low as 0.25 . Even in summer, the $\mathrm{D} / \mathrm{S}$ ratio did not much exceed 1.0.

Keywords: Aflaj, traditional irrigation, irrigation demand/supply ratio, efficiency, Athar, Oman.

\section{Introduction}

Agriculture in Oman is fully dependent on irrigation because most crop production areas receive only 100 to $200 \mathrm{~mm}$ of rainfall annually. Oman has 4,112 falaj, of which 3,017 are live Aflaj(افلاج), supplying about $680 \mathrm{Mm}^{3}$ /year of water, of which $410 \mathrm{Mm}^{3}$ are utilized by Aflaj users for domestic and agriculture. These Aflaj irrigate some 26,500 hectares (The Ministry 
of Regional Municipalities, Environment and Water Resources, 2001). The falaj (فلج) (singular of Aflaj) is defined as, a canal system, which provides water for a community of farmers for domestic and agricultural use. The term falaj is derived from an ancient Semitic root, which has the meaning "to divide", since the water shares in Aflaj are divided between the owners (Al-Ghafri, 2005). The local nomenclature of the falaj implies the system as a whole, including the collection and distribution areas. Aflaj in Oman can be classified into three types, depending on their source of water: Ghaili (غيلي), Daudi (داؤودي) , and Aini (عيني). However, the methods of administration and management are very similar. Only the Daudi type is similar to the Qanat irrigation system of Iran (AlGhafri et al., 2000).

The traditional way of irrigation scheduling varies from one falaj to another. Several methods are adapted for distributing water among farmers. The most common method is to divide the irrigation rotation (dawranist دوران ) over 4 to 20 days, depending on the falaj flow and the type of soil; each full day is divided to 48 athars, or 30 minutes, each athar is then divided to smaller divisions. Traditionally, farmers have used sundials in the daytime, and stars at night for timing their water shares in the field (Al-Ghafri et al., 2003).

Previous studies have considered water management on the farm scale within the falaj system (Norman et al., 1998a, 1998b, 2001). However, this study aims to analyze the overall irrigation performance of the falaj system, by considering the whole falaj as a single farming system unit, hence all the lands of the falaj are assumed to be irrigated during a fixed period (dawran). This paper illustrates a method for an estimation of falaj irrigation performance using irrigation demand over supply ratio (D/S).

\section{Site Description for the Study Area}

The villages of al-Dariz الدريز (N23 $19^{\prime}$ - E56 47') and al-Nujaid النجيد (N23 28 - E56 47') are located in the Ibri (ولاية عبري) district in the Dhahirah (الظاهرة) region in northern Oman. Ibri has 363 falaj, which is the second largest number of Aflaj among the 60 wilayats (districts) of Oman. These villages are located close to one of the world's driest deserts, Ar Rub'al Khali (الربع) known also as the "Empty Quarter". They have a negligible amount of rainfall.

There is no rain gauge installed in al-Dariz. However, there are rain gauges in two places in the same district at Ibri and Tanam (تنعم). From these two places, rainfall data have been collected by MRMEWR for 25 years (1975 - 1999). The average annual rainfall for these 25 years is $88 \mathrm{~mm} \mathrm{y}^{-1}$ (Ibri) and $85 \mathrm{~mm} \mathrm{y}^{-1}$ (Tanam). The maximum and minimum rainfall data are not available. The average annual rainfall for the period 1991 - 1998 was $133 \mathrm{~mm} \mathrm{y}^{-1}$ in al-Nujaid. Data for the period of study (May 2002 to April 2003) were collected by installing a rain gauge in the research area of al-Dariz.

Falaj al-Dariz is a large Daudi falaj (chain of wells) with a total channel length of $6,503 \mathrm{~m}$, of which $5,880 \mathrm{~m}$ is a tunnel. One of the two mother-wells of falaj al-Dariz has dried up. This falaj has good water quality. According to the MRMEWR (2001), water quality tests show an electrical conductivity (EC) of $480 \mu \mathrm{S} \mathrm{cm}^{-1}$ and $\mathrm{pH}$ of 8.0. Falaj al-Nujaid, on the other hand, is a medium size Daudi falaj located about $25 \mathrm{~km}$ upstream and north of falaj al-Dariz. Falaj alNujaid has one mother well located in the wadi bed of Wadi al-Kabir, $2.2 \mathrm{Km} \mathrm{m}$ from the first opening of the tunnel. Falaj al-Nujaid has a higher EC $\left(749 \mu \mathrm{S} \mathrm{cm}^{-1}\right)$ and similar $\mathrm{pH}$ (8.0) as falaj al-Dariz (MRMEWR, 2001).

Date palms (Phoenix dactylifera) occupy more than $90 \%$ of the cropping area of falaj al-Dariz and falaj al-Nujaid. Other crops cover negligible areas in these two aflaj and are planted seasonally. Winter crops, such as wheat, barely and garlic, are planted between October and November and harvested between March and April. Summer crops, such as onion, beans and corn, are planted between February and April, and harvested between June and September. However, these crops occupy a small portion of land and water compared with date palms.

\section{Materials and Methods}

\section{Irrigation Water Demand/Supply (D/S) ratio}

The ratio of crop water demand to irrigation supply (Demand over Supply ratio, D/S) was used for this study as suggested by Norman et al. (1998 a, b and 2001). A D/S ratio greater than 1.0 indicates that farmers are applying less water than plant require. $\mathrm{A} \mathrm{D} / \mathrm{S}$ ratio smaller than 1.0 indicates that farmers are over-irrigating. A minimum ratio of 0.6 is accepted for surface irrigation (Norman et al., 1998a).

The average daily water requirements (demand) for each month in the year were obtained from 
published official literature by the Ministry of Agriculture and Fisheries Wealth (Al-Nadi, 2003). A calibrated water level was used to determine the flow rate. The area was obtained from maps published by MRMEWR (2001). The quantity of water supplied per area (S) was calculated from the flow rate, time of application and area.

\section{Data collection}

Data were collected by direct fieldwork, interviews and a review of the literature. Rain data and field observations (such as sudden rise of water flow, unusual behavior of irrigators, etc.) were recorded during the course of this study. Contact with the falaj community and with members of the falaj administration was maintained throughout the study. Soil textural analyses and field capacity measurements were done in the laboratories of Sultan Qaboos University, Oman.

\section{Crop water requirements for date palm}

The data for the water requirements (ETc) for the date palm was retrieved from Al-Nadi (2003). The calculation was made for a plant density of 1 date palm per $15 \mathrm{~m}^{2}$. The estimation of ETc was based on the Penman-Monteith method (Richard et al., 1998).

\section{Water level}

Two data loggers were installed in falaj al-Dariz and falaj al-Nujaid on 25 May 2002. Solid-state high-duty loggers were used (STS model DL/N). Readings were recorded every hour. The last data were downloaded from the loggers on 25 April 2003 and 11 months data were successfully retrieved.

\section{Flow rate}

The flow rate was measured as close as possible to the demand area, to avoid errors created by water losses in the conveyance system. It was observed four times during the 11 months of water level reading, using a solid-state current meter (model: VALPORT.LTD VEM003). The average of three readings was taken at three different locations. The falaj width and depth of the water were also measured and recorded in every observation.

\section{Soil sampling}

Soil samples were taken from three farms, in the head, center and tail end of each falaj cropping area. In each farm, samples were taken from three locations at depths of 15, 30 and $45 \mathrm{~cm}$. Samples were analyzed for soil texture using a hydrometer and bulk density using core sampling method. The samples for determining the field capacity were collected from the field after 24 hours of full irrigation, and then the water content was obtained using the gravimetric method.

\section{Results and Discussion}

\section{Area}

According to MRMEWR (2001), the cropped area of falaj al-Dariz is 255.4 ha and 21.3 ha for falaj alNujaid. The area was estimated using GIS system after GPS land survey.

\section{Rainfall}

The effective rainfall during the study period was 44.1 $\mathrm{mm}$. Falaj al-Nujaid is located about $25 \mathrm{~km}$ up stream of al-Dariz, therefore the same rainfall data was used for al-Nujaid case study.

\section{Flow rate calibration}

By linear regression the following calibration equation was obtained for calculating the flow rate of falaj alDariz:

$$
\begin{aligned}
& \mathrm{Q}=99.1 \mathrm{H}^{0.22} \quad\left(\mathrm{R}^{2}=0.66\right) \\
& \mathrm{Q}=\text { the flow rate }\left(1 \mathrm{~s}^{-1}\right) \\
& \mathrm{H}=\text { the logger measured head }(\mathrm{cm})
\end{aligned}
$$

Figure 1 shows the hydrograph of falaj al-Dariz. The trend shows that the falaj flow was in the process of recession, since there was little rainfall during that period. An abnormal rise and recession in the flow rate occurred between September and October 2002. This was due to the falaj tunnel collapse.

The calibration equation for falaj al-Nujaid was:

$$
\mathrm{Q}=2.22 \mathrm{H}^{1.79} \quad\left(\mathrm{R}^{2}=0.85\right)
$$

Figure 2 shows the hydrograph of falaj al-Nujaid, with two adonolies. The hydrograph shows two adonolies in the flow rate. The first was observed in September 2002 and the second in April 2003. During this period, the upstream catchments of the wadi that feed the falaj experienced heavy rainfall. The tunnel of falaj al-Nujaid passes through a wadi bed, but it is not totally sealed. There are places where surface water can percolate into the tunnel. So, the high flows 


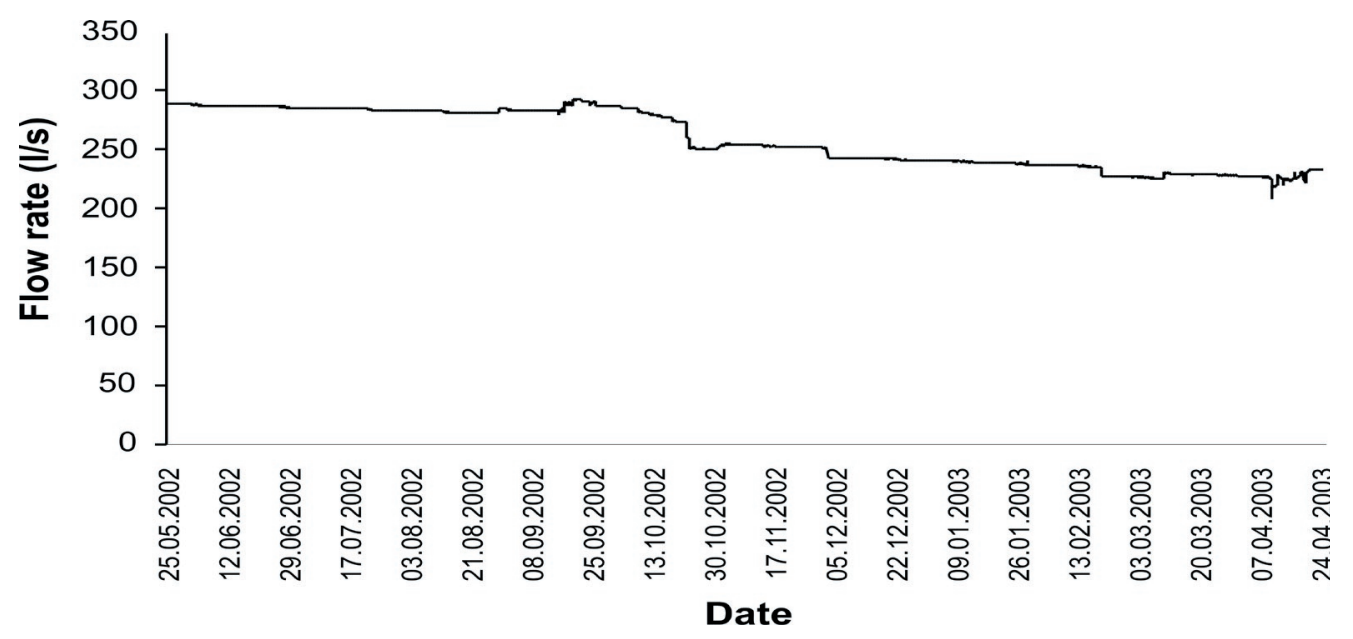

Figure 1. Hydrograph of falaj al-Dariz.

in September and April are not from groundwater but a temporary intrusion of surface flow. Local people said that it takes 6 months for the falaj flow rate to increase to high flow after heavy rain, then it remains with a steady flow for 4 to 5 years, even without any other heavy rain. However, the recent data are insufficient to verify this fact. Collection of hydrological data is needed for a longer period. In both flow rate calculations (of September and April), it should be noted that the high flow rate was obtained by extrapolating the regression curve. Thus, these values may include a large error. However, these high flows occur in short periods in few times, the overall error is insignificant.

\section{Soil analysis}

The soil texture of al-Dariz is dominated by clay loam with a bulk density of $1.43 \mathrm{~g} \mathrm{~cm}^{-3}$ and field capacity of $22 \%$ by volume. Falaj al-Nujaid has a sandy loam soil mixed with small gravels with a bulk density of $1.72 \mathrm{~g} \mathrm{~cm}^{-3}$ and a field capacity of $16.4 \%$ by volume. These results indicate that falaj al-Dariz has a finer

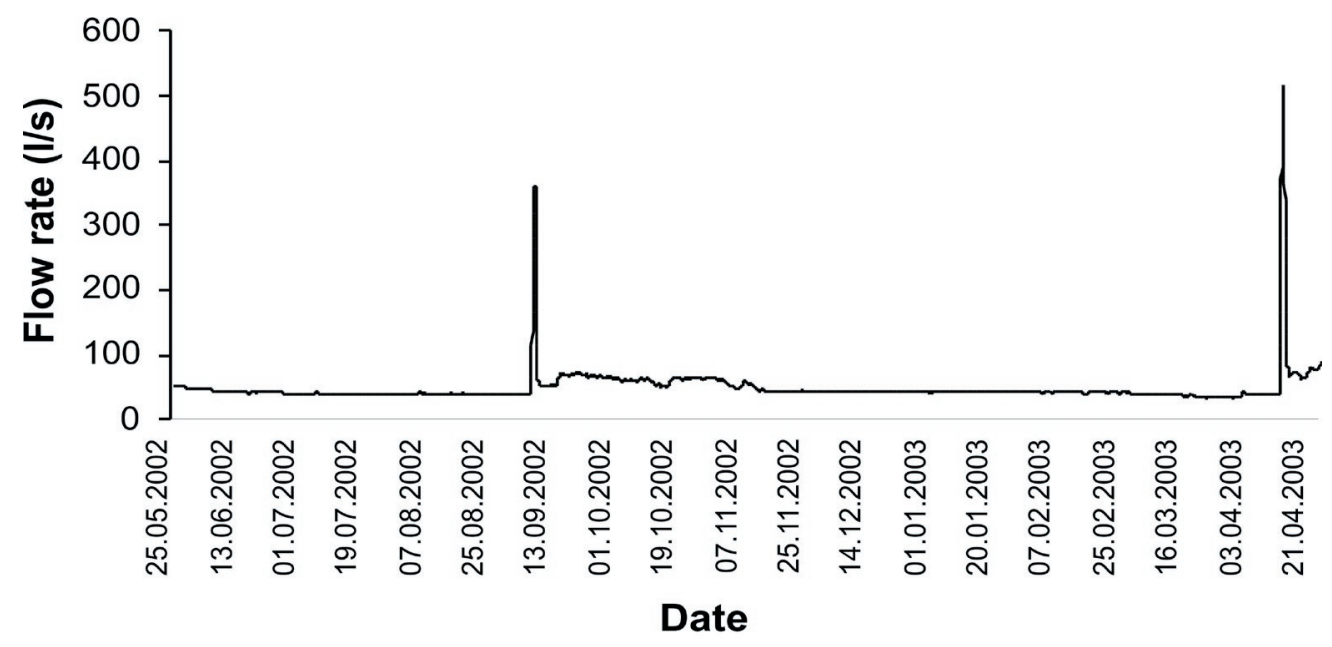

Figure 2. Hydrograph of falaj al-Nujaid. 


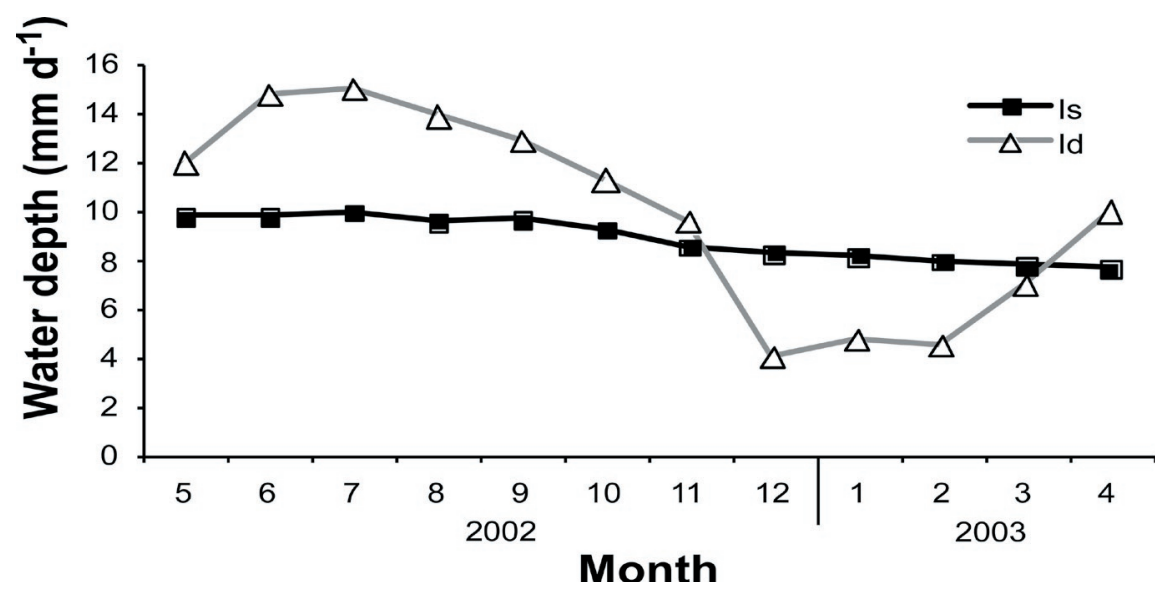

Figure 3. Monthly average irrigation demand and supply for falaj al-Dariz, 2002-2003.

soil texture with higher field capacity than falaj alNujaid. Hence, the dawran of falaj al-Dariz (19 days) is designed to be longer than the dawran of falaj alNujaid (10 days).

\section{Irrigation Water Demand/Supply (D/S) ratio for falaj al-Dariz \\ a) Annual $D / S$}

The logger started the first reading of the water head in the channel of falaj al-Dariz on 25 May 2002. The last reading retrieved from the logger was on 26 April 2003. For calculations, this period is called $T_{p}$ and the complete year period $\mathrm{T}_{\mathrm{y}}$. The total time during the period of observation $\mathrm{T}_{\mathrm{p}}$ was 8,047 hours. The total volume of water delivered to the field during $\mathrm{T}_{\mathrm{p}}$ was $7.487 \mathrm{Mm}^{3}$ and the total volume for the whole year was $8.151 \mathrm{Mm}^{3}$ with a yearly depth (volume/area) of $3,191 \mathrm{~mm}$. The total supplied water to the field including the effective rainfall was $3,235 \mathrm{~mm}$.

Based on Al-Nadi (2003) the total annual demand for date palms, $\mathrm{ETc}=3,620 \mathrm{~mm} \mathrm{y}^{-1}$, and the annual D/S can be calculated as:

$$
\mathrm{D} / \mathrm{S}=3,620 / 3,235=1.12 \text { or } 112 \%
$$

This result indicates that the date palms in al-Dariz are under irrigated as demand is higher than supply by $12 \%$ on a yearly basis.

\section{b) Monthly $\mathrm{D} / \mathrm{S}$}

The same criterion was used to calculate $\mathrm{D} / \mathrm{S}$ on a monthly basis. For each month, the average daily water delivered was calculated. This calculation includes the rainfall of April 2003.

From Figure 3, it can be seen that the patterns of demand and supply are not matched. While the water demand is higher in summer and lower in winter, the supplied water follows the hydrograph of the falaj. It is clear from the figure that the water supply of falaj alDariz was decreasing at the period of measurement.

From Figure 4, it is clear that the D/S was changing every month. From April to November, the falaj did not supply enough water to meet the crop water requirement, while in December, January and February, the falaj supplied more water than demanded. Only in March, was the D/S (0.90) is within the accepted range $(0.6-1.0)$. This means that the plants were stressed in summer and over-irrigated in winter. The highest D/S was in June (1.52) and the lowest was in December (0.49).

\section{Irrigation Water Demand/Supply ratio (D/S) for falaj al-Nujaid}

\section{a) Annual $\mathrm{D} / \mathrm{S}$}

The logger started the first reading of the water level in the channel of falaj al-Nujaid on 25 May 2002. The last reading retrieved from the logger was on 25 April 2003. For calculations, this period is $T_{p}$ and a complete one-year period $\mathrm{T}_{\mathrm{y}}$. The total time during the period of observation $T_{p}$ was 8,054 hours. Assuming that the flow rate of the 12 th month will be same as the average of previous 11 months, the total volume of water delivered to the field at $\mathrm{T}_{\mathrm{p}}$ was $1.315 \mathrm{Mm}^{3}$. The 


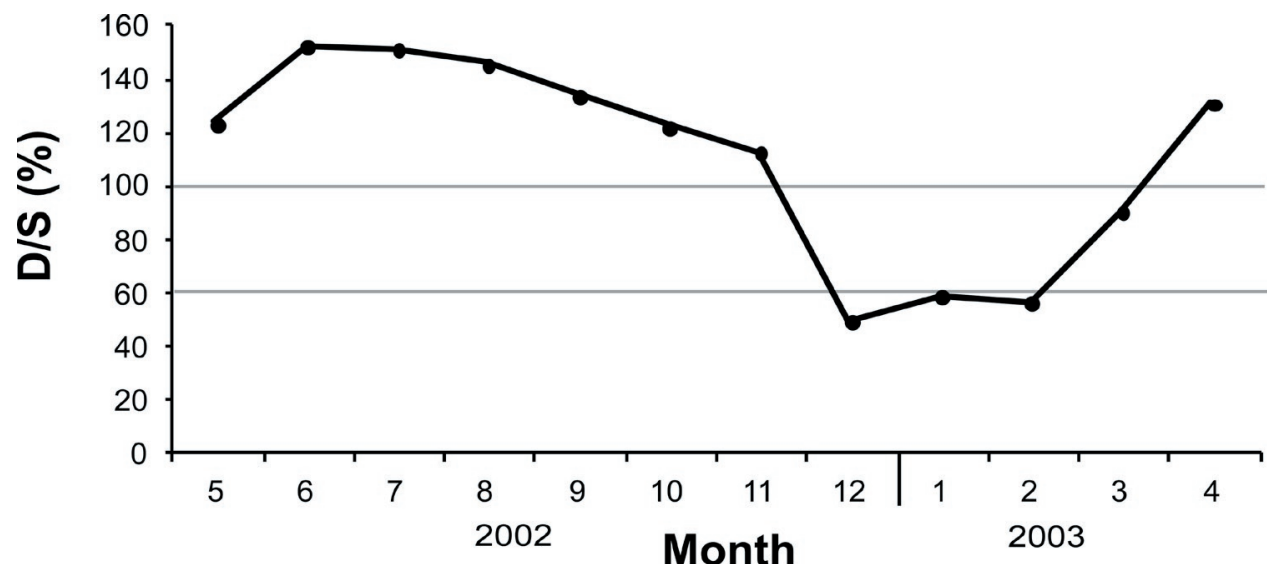

Figure 4. Monthly D/S for falaj al-Dariz, 2002-2003.

annual volume was $1.431 \mathrm{Mm}^{3}$ with a yearly depth of $6,723 \mathrm{~mm}$. The total supplied water to the field including the effective rainfall was $6,767 \mathrm{~mm}$.

The annual demand for date palm is ETc $=$ $3,620 \mathrm{~mm} \mathrm{y}^{-1}$ and the annual demand/supply can be calculated as:

$$
\mathrm{D} / \mathrm{S}=3,620 / 6,767=0.53 \text { or } 53 \%
$$

This result indicates that the demand area of falaj al-Nujaid is over irrigated on a yearly basis.

\section{b) Monthly $D / S$}

For each month, the average daily supply was calculated including the rainfall of April 2003. The supply of water peaked on September 2002 and April 2003, when the surface water entered the canal after rainfall (Figure 5). Over the whole year, falaj alNujaid supplied more water than the crops demanded. Compared with falaj al-Dariz, this falaj has light soil with relatively low field capacity. Generally, more water needs to be applied to the soil in al-Nujaid than in al-Dariz.

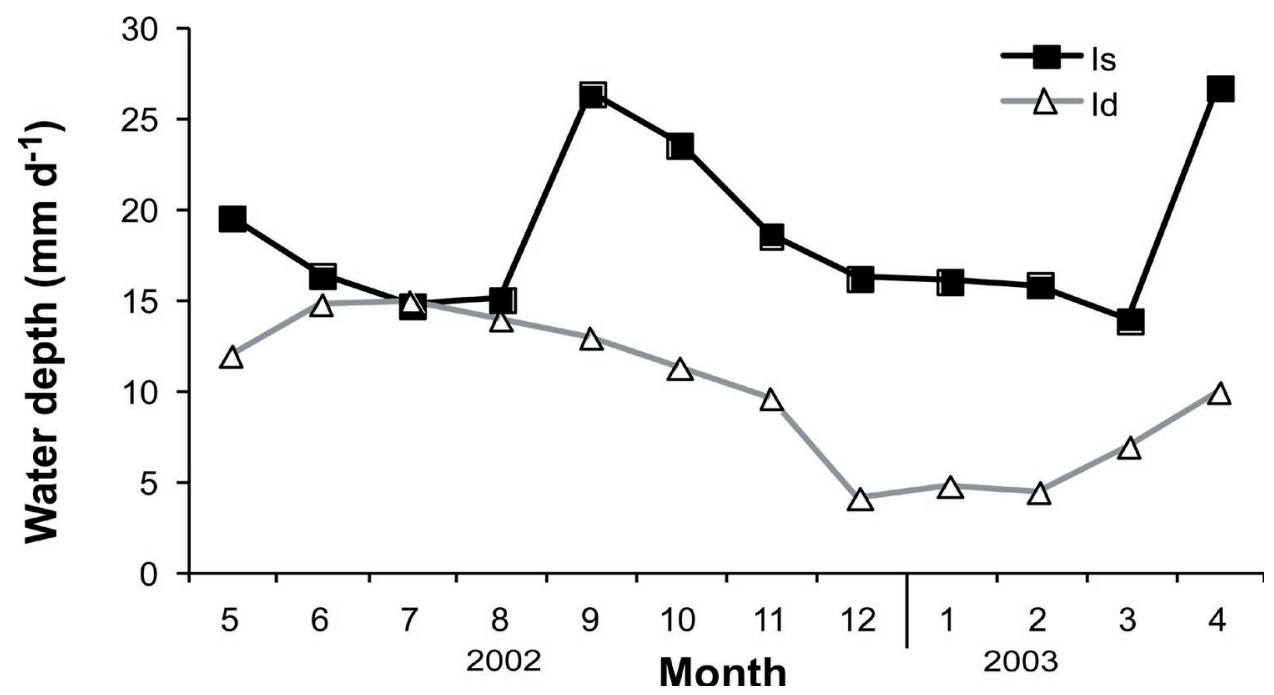

Figure 5. Monthly average irrigation demand and supply for falaj al-Nujaid, 2002-2003. 


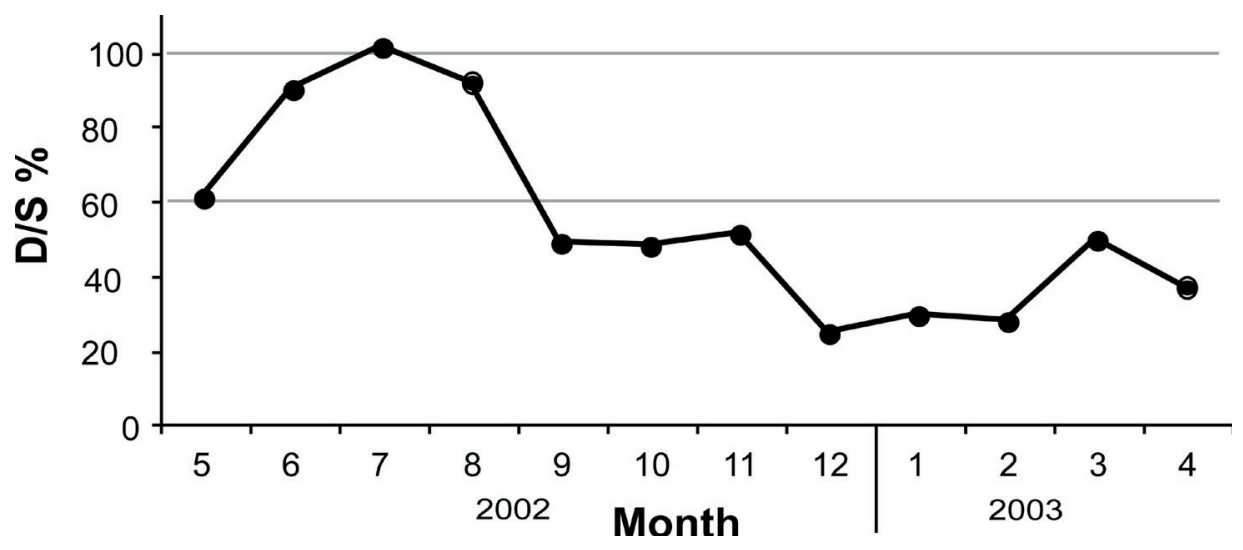

Figure 6. Monthly D/S for falaj al-Nujaid, 2002-2003.

From Figure 6, it can be seen that falaj al-Nujaid supplied water more in winter than it did in summer. From May 2002 to August 2002, the falaj performed well, with $\mathrm{D} / \mathrm{S}$ values between 0.6 and 1.0. However, from September 2002 to April 2003, the falaj wasted tremendous amounts of water, with a minimum $\mathrm{D} / \mathrm{S}$ value in December 2002 (0.25).

\section{Conclusion}

In falaj al-Dariz the date palms were slightly under irrigated on a yearly basis. On a monthly basis, the performance of the falaj irrigation system was different. In winter, the D/S was below 0.6 and in summer it was above 1.0. This means that falaj alDariz wasted water in winter but the plants were stressed in summer. On the other hand, falaj al-Nujaid was supplying more water than the date palms needed all year round. In winter the $\mathrm{D} / \mathrm{S}$ ratio was as low as 0.25 . Even in summer, the $\mathrm{D} / \mathrm{S}$ ratio did not much exceed 1.0. Probably, the reason for the low $\mathrm{D} / \mathrm{S}$ in this falaj is because it has a lighter soil that needs more water to be applied. In this falaj, farmers are irrigating more frequently than in falaj al-Dariz.

The data obtained from this study was adequate to meet the objective of roughly estimating the irrigation performance of aflaj. However, further research is needed to precisely evaluate the hydrological and agricultural systems of aflaj. This requires measuring more parameters for longer periods. For falaj hydrological studies, rainfall, flow rate and wadi flood records are necessary. For detailed irrigation performance evaluation, on-field weather data should be obtained with real-time soil moisture content in the soil, within and below the root zone. For measuring areas of land use, high-resolution satellite images can be used, capturing each cropping season every year. A complete understanding of the falaj water management may not be attained unless further measurements on water and soil quality are made, as well as, economical evaluation of the input and output of the falaj system related to irrigation.

\section{Acknowledgement}

The author acknowledges the technical, logistical and intellectual support that received from Hokkaido University, Sapporo, Japan, the United Nations University, Tokyo, Japan and Sultan Qaboos University, Muscat, Oman. The author also acknowledges the reviewers who helped in improving the first draft of this paper.

\section{References}

Allen, R.G, L.S. Pereira, D. Raes and M. Smith. 1998. Crop evapotranspiration - Guidelines for computing crop water requirements. FAO Irrigation and drainage paper 56, $301 \mathrm{pp}$. http://www.fao.org/ docrep/X0490E/x0490e00.htm\#Contents

Al-Ghafri, A.S. 2005. Aflaj of Oman: History, engineering and management (in Arabic). In: Nizwa (Cultural Journal), Oman. 44:11-20.

Al-Ghafri, A.S., T. Inoue and T. Nagasawa. 2003. Irrigation scheduling of Aflaj of Oman: Methods and its modernization. In: UNU Desertification Series No. 5, Sustainable Management of Marginal 
Dry Lands, Zafar Adeel (Editor), The United Nations University, Tokyo, Japan. pp. 147-166.

Al-Ghafri, A.S., T. Inoue, T. Nagasawa and W.R. Norman. 2000. Aflaj irrigation systems of Oman, the way of water distribution. In: Proceeding of The XIV Memorial CIGR World Congress 2000, in Tsukoba, Japan, November 28 - December 1, 2000, pp. 1128-1133.

Al-Nadi, A.H. 2003. Index Guide for Crop Water Requirements in the Sultanate of Oman. (الدليل) (الإرشـادي لتقدير الاحتياجات المائية في السلطنة of Agriculture and Fisheries Wealth, Oman, pp. 10-11.

Ministry of Regional Municipalities, Environment and Water Resources (MRMEWR). 2001. Aflaj Inventory Project Summary Report, The Sultanate of Oman, pp. 9-13.
Norman, W.R, W.H. Shayya and A.S. Al-Ghafri. 1998a. Irrigation Water Costs and Management Practices Among Farms in Northern Oman. Journal of Scientific Research-Agricultural Sciences, Sultan Qaboos University, Oman. 3:1-8.

Norman, W.R., W.H. Shayya, A.S. Al-Ghafri and I.R. McCann. 1998b. Aflaj irrigation and on-farm water management in Northern Oman. Irrigation and Drainage Systems 12:35-38.

Norman, W.R., A.S. Al-Ghafri and W.H. Shayya. 2001. Water use performance and comparative costs among surface and traditional irrigation systems in northern Oman. In: Water in the Arabian Peninsula: Problems and Policies. K. Mahdi (Editor). Ithaca Press, Reading, UK. pp. 203-220. 